\title{
KEBANGKITAN TAREKAT KOTA
}

\author{
Ahmad Amir Aziz \\ Institut Agama Islam Negeri Mataram, Indonesia \\ E-mail: amir.iain@gmail.com
}

\begin{abstract}
This article tries to analyze the revival of mystical order (tarekat) in urban areas. Experiences reveal that the development of mystical orders in the Muslim world is not free from criticism, either from the insiders or the outsiders. However, mystical orders still exist, and this fact is characterized by the development of different mystical groups in various cities. Political, social and economic factors influence the fluctuation of mystical orders. This article argues that in a number of countries and in Indonesia, the mystical orders have contributed significantly to the socioreligious life of Muslims. The mystical orders become stronger as they are supported by the involvement of middle class group, media publication, and internal strength embedded in the very tradition of mystical orders. The influx of middle class Muslims to the networks of tarekat brings the fresh wind of change since their engagement provides the internal dynamic of tarekat which encounters external influences on the one hand, and the continuing drive to develop on the other.
\end{abstract}

Keywords: Sufism, sufi order, murshid, middle class.

\section{Pendahuluan}

Di sepanjang sejarah Islam terdapat kritik yang cukup tajam terhadap sufisme, lebih khusus pada institusi tarekat (ordo sufi). Pada abad ke-18, opisisi terkuat terhadap tarekat datang dari gerakan Wahabîyah yang tengah berkembang. Pada era modern, para pembaru mengritik keras tarekat karena dinilai mengeksploitasi kepercayaan takhayul yang berakar kuat dalam masyarakat awam.

Tidak sedikit para peneliti Barat yang mempunyai pandangan bahwa tarekat adalah gerakan yang dipastikan akan merosot, karena negara-negara Muslim telah mengikuti model-model pembangunan Barat, dan kaum elit terpelajar telah meninggalkan bentuk-bentuk organisasi religius tradisional. Penilaian dan kritik tajam dari A.J. 
Arbery merupakan representasi dari pandangan tersebut. Dia dengan keras mencela kebobrokan tarekat di Mesir dan menyebut shaykhshaykhnya sebagai kekuatan jahat yang melakukan konspirasi untuk menipu rakyat. ${ }^{1}$

Clifford Geertz, yang terkenal berkat penelitiannya di Pare itu, mengungkapkan pandangan serupa bahwa tarekat-tarekat hanyalah perkumpulan mistik yang cenderung rahasia yang diikuti oleh orangorang berusia lanjut. Suasananya diliputi oleh ilmu kekebalan, uji kekuatan, puasa berkepanjangan, dan pelakunya terbiasa memutar tasbihnya selama berjam-jam. Eksistensi kelompok tarekat ini, meskipun tidak musnah sama sekali, telah merosot jumlahnya semenjak bangkitnya arus modernisasi yang menantangnya dengan keras. $^{2}$

Di sisi lain menurut $H$. Lammens, sufisme mengalami kemerosotan seiring dengan terbukanya negeri Muslim dalam menerima pengaruh Barat. ${ }^{3}$ Bahkan Louis Massignon, sebagaimana disebut Azra, berpendapat bahwa masa modern merupakan akhir efektif dari tasawuf dan tarekat. Pada pertengahan abad ke-20 ia nyatakan bahwa tarekat telah lumpuh karena terus menerus mendapat serangan dari elit modern Muslim. Konstelasi ini diperkuat pula dengan anggapan bahwa spiritualisme yang menjadi inti tasawuf dan tarekat tidaklah cocok dengan modernitas yang terus pula meningkat momentumnya di hampir seluruh negeri Muslim. ${ }^{4}$

Dari keseluruhan pandangan di atas tampak sekali penilaiannya yang minor atas tarekat, kritik yang tajam, hingga masa depan tarekat yang telah tertutup. Yang patut dipersoalkan, apakah pandangan semacam itu masih cukup kuat dan berlaku untuk konteks akhir abad ke-20 dan awal abad ke-21? Tampaknya penilaian semacam itu tidak bisa lagi dipertahankan. John O. Voll menulis, berlainan dengan oposisi dan prediksi-prediksi itu tarekat justru semakin kuat secara menakjubkan di sebagian besar dunia Islam serta dalam komunitas

\footnotetext{
1 A.J. Arbery, Sufism: An Account of the Mystic of Islam (London: George Allen dan Unwin, 1950), 122.

2 Clifford Geertz, Abangan Santri Priyayi dalam Masyarakat Jawa, terj. Aswab Mahasin (Jakarta: Pustaka Jaya, 1989), 248-249.

${ }^{3}$ H. Lammens, Islam: Beliefs and Institutions (New Delhi: Oriental Bokks Reprint Corporation, 1979), 138.

4 Azyumardi Azra, "Tasawuf dan Tarekat", dalam Taufik Abdullah (ed.), Ensiklopedi Tematis Dunia Islam: Dinamika Masa Kini, Vol. 6 (Jakarta: Ichtiar Baru van Hoeve, 2002), 378.
} 
Muslim tempat mereka menjadi minoritas. Dalam konteks yang berubah pada akhir abad ke-20, tradisi-tradisi tarekat sufi memiliki kekuatan khusus dalam situasi yang mengandung derajat pluralitas pemikiran keagamaan yang demikian tinggi. ${ }^{5}$

Sealur dengan Voll, Martin van Bruinessen berpandangan bahwa meskipun tarekat merupakan gejala keagamaan yang hidup subur di kawasan pedesaan, ia tetap bertahan dan bahkan menyebar ke kota. Katanya, Some of the tarekat have found a new following among the urban population and not only among its most traditional segment. Certain tarekat teachers appeal to an educated public and have disciples among the highest social circles. ${ }^{6}$

Dari gambaran di atas jelas bahwa kubu pertama, outsider perspective, menyerang tarekat sedemikian keras dan memandangnya sebagai tidak punya masa depan. Sedangkan mereka yang masuk kelompok kedua, memberikan apresiasi potitif atas peran konkret tarekat untuk masa sekarang dan akan datang. Pemikiran dan fakta yang segera disajikan dalam tulisan ini akan memperkuat pandangan dan argumentasi pihak yang pro, insider perspective, dengan lebih menekankan pada dinamika tarekat dan faktor-faktor yang mempengaruhinya, sehingga ia tetap dapat bertahan sampai era sekarang dan diminati oleh kalangan kelas menengah kota.

\section{Pemetaan Kajian tentang Tarekat}

Bagian ini terlebih dahulu menyajikan sekilas beberapa hasil penelitian tentang tarekat yang sesungguhnya telah well-explored. Tentang sejarah dan perkembangan tarekat, J.S. Trimingham menulis, The Sufi Orders in Islam (1973), sebuah karya berbobot dengan rujukan sumber-sumber primer yang kaya. Selain membahas asal-usul tarekat, Trimingham juga menelusuri dinamika, pertumbuhan dan penyebaran tarekat-tarekat penting di dunia Islam. Annimarie Schimmel dalam Miystical Dimensions of Islam (1975) mengulas banyak hal tentang doktrin sufisme, yang mana perihal sejarah tarekat dikemukakannya

5 John O. Voll, "Sufism: Tarekat-tarekat Sufi", dalam John L. Esposito (ed.), Ensiklopedi Oxford Dunia Islam Modern, Vol. 5, terj. Eva, et al. (Bandung: Mizan, 2002), 223.

${ }^{6}$ Martin van Bruinessen, "The Origin and Development of Sufi Order (Tarekat) in Southeast Asia", Studia Islamika, Vol. 1, No. 1 (April-Juni 1994), 1-23. Uraian penting lain seputar perkembangan tarekat ditulis dalam Kitab Kuning Pesantren dan Tarekat (Bandung: Mizan, 1999). 
dalam bab ke-5. ${ }^{7}$ Martin van Bruinessen, sarjana pewaris tradisi etnografis Belanda yang terkenal dengan kedalaman refleksinya ini menulis dua karya penting, Tarekat Naqshabandîyah di Indonesia (1992) dan Kitab Kuning Pesantren dan Tarekat (1995), di mana keduanya menjadi rujukan penting dalam studi-studi sufisme dan tarekat di Indonesia. Lebih lanjut, semacam ensiklopedi tentang pertumbuhan dan dinamika tarekat-tarekat utama di dunia Islam dapat dilihat dalam karya Sayyed Hossein Nasr (ed.), Islamic Spirituality: Manifestation (1997), dan Sri Mulyati (ed.), Tarekat-tarekat Muktabarah di Indonesia (2004), yang memuat delapan tarekat yang berpengaruh di Indonesia dan empat tarekat lain yang berkembang di kawasan dunia Islam.

Nicola A. Ziadeh menulis dengan cukup baik tentang eksistensi peran sosial-politik Tarekat Sanûsiyah. Dia berhasil membuktikan bahwa tarekat ternyata tidak sekadar berkutat pada masalah-masalah normatif dan 'ubûdîyah belaka, namun tak jarang justru fungsi politisnya lebih menonjol. ${ }^{9}$ Tulisan Tommy Christomy, "Shațârîyah Tradition in West Java: the Case of Pamijahan", mengilustrasikan silsilah tarekat ini dan penyebarannya di Jawa Barat. ${ }^{10}$ Sementara itu Muhaimin meneliti peran pesantren Buntet Cirebon sebagai agen penyebaran tarekat Shațtârîyah dan Tîjânîyah. Yang terakhir ini, meskipun awalnya sulit diterima di komunitas NU dan karena adanya persaingan perebutan pengikut, pada akhirnya Tijânîyah diakui juga sebagai tarekat muktabarah. ${ }^{11}$ Kedudukan dan peran penting pesantren dan kiai dalam penyebaran tarekat juga diperkuat oleh hasil studi Khairul Anwar "Al-Ma'âhid al-Turâthîyah wa al-Shuyûkh wa alTuruq al-Ṣûfiyah” (1998). ${ }^{12}$ Sementara itu tentang Tarekat Shâdhilîyah

\footnotetext{
7 Annimarie Schimmel, Mystical Dimensions of Islam (Chapel Hill: The University of Nort Carolina Press, 1975), 228-258.

${ }^{8}$ Seyyed Hossein Nasr, Ensiklopedi Tematis Spiritualitas Islam, terj. M. Solihin, et al. (Bandung: Mizan, 2003).

${ }_{9}$ Nicola A. Ziadeh, Sanusiyah: A Study of a Revivalist Movement in Islam (Leiden: E.J. Brill, 1983).

10 Tommy Christomy, "Shattâriyah Tradition in West Java: the Case of Pamijahan", Studia Islamika, Vol. 8, No. 2 (2001).

11 Muhaimin, "Pesantren and Tarekat in Modern Era: An Account on the Transmission of Traditional Islam in Java", Studia Islamika, Vol. 4 No. 1 (1997).

12 Khairul Anwar, "Al-Ma'âhid al-Turâthiyyah wa al-Shuyûkh wa al-Ṭuruq alȘûfiyah”, Studia Islamika, Vol. 5 No. 1 (1998).
} 
dan kiprah pengikutnya dalam bidang bisnis di Kudus pernah diteliti oleh Rajasa Mu'tashim dan A. Munir Mulkhan (1998). ${ }^{13}$

Para peneliti Indonesia cukup banyak yang tertarik melihat dinamika tarekat dari sudut pandang politik terbukti dari sejumlah terbitan yang muncul. Abd Rahim Yunus menulis, Posisi Tasanuf dalam Sistem Kekuasaan di Kesultanan Buton pada Abad ke-19 (1995). Mahmud Sujuthi menelorkan, Politik. Tarekat Qadiriyah wa Naqshabandîyah Jombang (2001), hasil penelitian disertasinya dari Universitas Airlangga Surabaya. Ajid Tohir menulis, Gerakan Politik Kaum Tarekat: Telaah Historis Gerakan Antikolonialisme Tarekat Qadiriyah wa Naqshabandîyah di Pulau Jawa (2002). ${ }^{14}$ Endang Turmudi, peneliti LIPI alumni Department of Sociology Australian National University, menulis disertasi yang kemudian diterbitkan dalam edisi Indonesia, Perselingkuban Kiai dan Kekuasaan (2004). ${ }^{15}$ Selain yang telah tersebut, dua buah tesis masing-masing karya Nur Syam, Pembangkangan Kaum Tarekat (2004), ${ }^{16}$ dan M. Muksin Jamil, Tarekat dan Dinamika Sosial Politik (2005), ${ }^{17}$ juga merupakan hasil penelitian yang patut dicermati.

Sudut pandang lain yang agaknya lebih dekat dengan tema tarekat kota ini adalah tiga buah hasil penelitian, masing-masing karya Dadang, Kharisuddin, dan Syafi'i Mufid. Yang pertama menulis Tarekat dalam Islam: Spiritualitas Masyarakat Modern (2002), ${ }^{18}$ hasil penelitian seputar perilaku keagamaan pengikut Tarekat Qâdirîyah wa Naqshabandîyah (TQN) di Kotamadya Bandung. Kharisuddin Aqib menghasilkan buku, Inabab: Jalan Kembali dari Narkoba Stres dan Kehampaan Jiwa (2005), yang memotret metode dan terapi spiritual ala TQN di pondok Inabah Suryalala atas mereka yang pernah terkena narkoba. Sementara itu Ahmad Syafi'i Mufid menulis, Tangklukan Abangan dan Tarekat (2006). Studi ini cukup menarik karena menyajikan hipotesis tentang kebangkitan kembali tarekat di pedesaan serta revitalisasi sufisme perkotaan.

\footnotetext{
13 Rajasa Mu’tashim dan A. Munir Mulkhan, Bisnis Kaum Sufi (Yogyakarta: Pustaka Pelajar, 1998).

14 Ajid Tohir menulis, Gerakan Politik Kaum Tarekat: Telaah Historis Gerakan Antikolonialisme Tarekat Qadiriyah wa Naqshabandîyah di Pulau Jawa (Bandung: Pustaka Hidayah, 2002).

${ }^{15}$ Endang Turmudi, Perselingkuhan Kiai dan Kekuasaan (Yogyakarta: LKiS, 2004).

${ }^{16}$ Nur Syam, Pembangkangan Kaum Tarekat (Surabaya: Lepkiss, 2004).

17 Muksin Jamil, Tarekat dan Dinamika Sosial Politik (Yogyakarta: Pustaka Pelajar, 2005).

18 Dadang Kahmad, Tarekat dalam Islam: Spiritualitas Masyarakat Modern (Bandung: Pustaka Setia, 2002).
} 


\section{Pertumbuhan Tarekat di Sejumlah Kawasan}

Harus diakui, memang terjadi pasang surut dan dinamika yang cukup kompleks berkaitan dengan berkembangnya tarekat di suatu wilayah. Faktor-faktor politik, sosial, dan ekonomi turut mempengaruhi bagaimana ia mengalami fluktuasi. Namun yang jelas, keberadaan tarekat hingga masa kontemporer ini tidak dapat dinafikan dan bahkan tetap memainkan peran penting dalam kehidupan masyarakat. Ini terjadi di banyak negeri Muslim seperti Mesir, Turki, Sudan, Senegal, Afrika Selatan, Indonesia, dan negeri-negeri bekas jajahan Soviet. ${ }^{19}$

Di Mesir, tarekat, terutama Cabang Shâdhilîyah yang reformis, telah memberikan jalan keluar bagi sebagian orang untuk mengungkapkan ekspresi religius mereka yang telah dilarang, bersamaan dengan adanya pengawasan ketat pemerintah atas aktivitas al-Ikhwân al-Muslimûn. Bagi mereka yang mencari ketenangan, ketenteraman, persaudaraan, dan bimbingan spiritual, tarekat-tarekat sufi paling tidak telah memberikan perlindungan sementara dari tekanan perubahan dramatis di dunia sekitar mereka. Pada tahun 1960, ada 21 tarekat yang terdaftar dalam Dewan Tertinggi Tarekattarekat Sufi (Supreme Council of Sufi Order), selain beberapa tarekat kecil yang tidak terdaftar. ${ }^{20}$ Meskipun hubungan antar-tarekat tidak selamanya harmonis dan bahkan persaingan antar-guru tarekat tidak dapat dihindarkan lagi, keberadaan kelompok tarekat-tarekat di Mesir patut diperhitungkan oleh pemerintah, terutama setelah belakangan muncul kecenderungan gerakan tarekat yang lebih moderat.

Di Turki, meskipun tarekat pernah dilarang dan pusat kegiatan tarekat (tekke) yang jumlahnya cukup banyak di berbagai kota tidak boleh buka, energi kaum sufi malah tersalur melalui politik lewat pembentukan "Gerakan Nurculuk" (pengikut Said Nursi). Ia mempunyai keanggotaan yang longgar namun pada esensinya tetap berakar pada tradisi Naqshabandîyah. Tokoh-tokoh gerakan ini bahkan secara kreatif dan imajinatif mengambil alih berbagai kosakata tasawuf yang digunakan Ibn 'Arabî untuk aktivitas politik. Gerakan Nurculuk mulai memperoleh pengaruh dalam kancah politik Turki

\footnotetext{
${ }^{19}$ Elizabeth Sirriyeh, Sufi dan Anti Sufi, terj. Ade Alimah (Yogyakarta: Pustaka Sufi, 2003), 210. Bandingkan dengan Nikki Keddie (ed.), Scholars Saints and Sufis (Barkeley, Los Angeles, dan London: University of California Press, 1972), 367-384.

${ }^{20}$ Sirriyeh, Sufi, 210.
} 
sejak tahun 1950-an melalui Partai Demokratik yang lebih ramah terhadap Islam. ${ }^{21}$

Di Sudan, beberapa tarekat yang kuat berhasil menunjukkan dinamikanya yang signifikan, ditandai dengan adanya vitalitas pemimpin religius sufi khususnya yang ditunjukkan oleh keluarga Mirghânî dari tarekat Khatmîyah dari tradisi reformasi Idrîsî dan juga dari kelompok Mahdîyah. ${ }^{22}$ Mereka dapat mengatur secara lebih efektif dalam mengatasi perbedaan pandangan antara kaum religius tradisional dengan pandangan mereka yang menerima pendidikan Barat. Selama tahun-tahun Perang Dunia, pemimpin tarekat Khatmîyah, Sayyid 'Alî al-Mirghânî dan Sayyid 'Abd al-Raḥmân alMahdî dari tarekat Mahdîyah, dengan lancar membangun hubungan dengan orang-orang "sekuler" tersebut. Setelah Perang Dunia II, kedua kelompok tersebut dengan mahirnya dapat mencapai kembali kredibilitas dan dukungan lokal. Bahkan setelah memperoleh kemerdekaan pada tahun 1956, tarekat-tarekat tersebut masih mempunyai jumlah anggota dalam skala besar dan berpengaruh di kalangan para politisi nasionalis baru.

Hal yang sama dialami oleh berbagai tarekat di Senegal, terutama setelah ia memperoleh kemerdekaannya dari Perancis tahun 1960. Tiga tarekat besar telah mengumpulkan anggota sekitar $97 \%$ umat Muslim di negara tersebut. Umat Muslim merupakan 78,5\% dari jumlah penduduk, para penganut agama-agama tradisional mencapai $18 \%$, dan Katolik Roma 3,5 \%. Tarekat yang paling banyak anggotanya adalah Tîjânîyah dengan 1,4 juta anggota. Tarekat Murîdiyah menempati posisi kedua dengan jumlah anggota 575.000 orang, yang berusaha menjalankan peranan penting dalam ekonomi politik Senegal dengan membuka tanah yang sebelumnya tidak dimanfaatkan untuk produksi kacang yang digarap oleh para murid yang taat dalam proses ekspansi yang cepat sejak 1920 sampai 1960an. Urutan ketiga adalah tarekat Qâdirîyah dengan jumlah anggota sekitar 400.000 orang. ${ }^{23}$

\footnotetext{
21 Azra, "Tasawuf", 390.

22 John O. Voll, "Mahdis, Walis and New Men in the Sudan", dalam Nikki Keddie (ed.), Scholars Saints and Sufis (Barkeley, Los Angeles, dan London: University of California Press, 1972), 367-384.

23 Sirriyeh, Sufi, 212-213. Penjelasan tentang keberadaan tarekat di Senegal dapat dibaca dalam dua karya Donal B. Cruise O'Brien, The Mourides of Senegal (Oxford: Oxford University Press, 1971), dan Saints and Politicians: Essays in the Organization of a Senegalese Peasant Society (Cambridge: Cambridge University Press, 1975).
} 
Dalam beberapa kasus gerakan sufisme secara sadar menjadi gerakan politik untuk melawan serangan dari kelompok anti-sufi, seperti yang terjadi di Nigeria dan Ghana, dan juga Ahbashî di Lebanon yang mengambil nama dari pendirinya, Shaykh 'Abd Allâh al-Habshî, yang berasal dari Ethiopia tetapi tinggal di Beirut sejak 1950. Kelompok ini mendapat dukungan khususnya dari terakat Qâdirîyah, Rifấîyah, dan Naqshabandîyah. ${ }^{24}$

Di Asia Tengah, kontrol-kontrol pemerintah Soviet terhadap aliran sufi tidak begitu berhasil. Secara umum, semakin jauh dari Moskow, para pejabat semakin tidak menerapkan kebijakan pemerintah, bahkan mungkin mereka sendiri menjadi pengikut suatu tarekat. Pada tahun 1979, di Asia Tengah paling sedikit terdapat 500.000 pengikut tarekat dari 27 juta orang penduduk. ${ }^{25}$ Jika dilihat prosentasenya, jelas jumlah itu tidak signifikan. Yang lebih adil adalah melihat kondisi ketertindasan dan tekanan yang dialami penduduk Muslim kawasan ini, sehingga sebagian kecil mereka yang setia menganut tarekat harus diberikan apresiasi yang layak.

Di kawasan Afrika, tarekat Sanûsîyah memiliki peran penting. Tarekat ini yang didirikan di Makkah tahun 1837 oleh Muhammad b. 'Alî al-Sanûsî (1787-1857), yang kemudian menyebar ke Libya dan wilayah sekitarnya. Di bawah kepemimpinan Sayyid al-Mahdî, tarekat Sanûsiyah menjadi kekuatan yang tangguh di hampir seluruh kawasan Gurun Sahara. Pada awal abad ke-20 tarekat Sanûsîyah memiliki ratusan zâmýah sampai ke Timbuktu, Afrika Tengah, dan sekaligus menguasai jalur perdagangan trans-Sahara. Kekuatan tarekat ini sedemikian rupa sehingga memaksa Italia untuk menyerah. Operasi militer yang dilakukan Inggris di Libya seusai Perang Dunia II pada akhirnya menempatkan Sayyid Idrîs, pemimpin Tarekat SanûsîyahIdrîsîyah sebagai penguasa Kerajaan Libya.

Sementara itu di Afrika Selatan banyak aliran tarekat yang berkembang, misalnya Qâdirîyah, Naqshabandîyah, Chistîyah, dan 'Alawiyah. Aliran-aliran berperan penting dalam gerakan pemantapan keislaman di era kontemporer, bahkan bisa bersaing secara kompetetif dengan gerakan dakwah yang juga sama-sama berkembang, seperti

24 A. Nizar Hamzeh dan R. Hrair Dekmejian, "A Sufi Response to Political Islamism: Al-Ahbasy of Lebanon”, International Journal of Middle East Studies, 28 (1996), 217-229.

${ }^{25}$ J.E.A. Johansen, "Sufisme dan Politik", dalam John L. Esposito (ed.), EnsiklopediOxford Dunia Islam Modern, Vol. 5, terj. Eva, et al. (Bandung: Mizan, 2002), 237. 
Islamic Propagation Centre, Islamic Missionary Society, dan Jama'ah Tabligh. ${ }^{26}$

Seiring dengan kebangkitan kembali di dunia Islam, tarekat juga menyebar hingga ke Barat. Di Amerika, sufisme dan tarekat diperkenalkan pada awal abad ke-20 oleh Shaykh Inayat Khan, pemimpin tarekat Chistîyah yang pemikirannya mengarah pada penyatuan umat dalam kerangka perdamaian. Tarekat asal Asia Selatan ini memiliki basis kuat di India, Pakistan, dan Bangladesh, serta sempat menyebar ke wilayah Afganistan dan Khurasan. Dalam sejarahnya, kaisar-kaisar Mughal mulai Akbar (w.1605) sampai akhir dinasti ini tahun 1857 memiliki hubungan kuat dengannya. Pada gilirannya sampai abad ke-21 tarekat ini tetap dapat berkembang, dan di Barat dikenal sebagai drunken sufism karena ciri samâ' dan ekstasenya. Setelah Inayat Khan berhasil memperkenalkan tarekat ini di negeri adidaya itu, ajarannya dilanjutkan oleh anaknya, Pir Vilayat Inayat Khan, tokoh yang sangat populer di lingkungan kelompok New Age.

Naqshabandî Haqqânî merupakan tarekat lain yang berkembang di AS. Haqqânî adalah nama seorang murshid Naqshabandî yang ke40, lengkapnya bernama Shaykh Nâzim 'Âdil al-Qubruzî al-Ḥaqqânî, kelahiran Cyprus 23 April 1922 dari keluarga Sayyid (keturunan Rasulullâh baik dari pihak ayah maupun ibu). ${ }^{27}$ Dia menawarkan gagasan-gagasan hangat perihal kualitas-kualitas yang dibutuhkan manusia dan berakar pada basis sharî́ah. Di kelompoknya yang kemudian lebih populer dengan sebutan tarekat NaqshabandiHaqqâni, Shaykh Nâzim dipadang sebagai Sultân al-Awliyâ’. Perkembangan tarekat ini di benua Amerika berada di tangan khalifahnya yang sekaligus menantunya, Shaykh Muhammad Hishâm Kabbânî. Tidak tanggung-tanggung, di kota-kota besar seperti New York, Washington, California, Texas, Michigan, dan Arizona, terdapat pusat-pusat zikir (haqqânî centre). Tarekat ini juga berkembang di 20

\footnotetext{
${ }^{26}$ Muhammed Haron, "The Dawah Movements and Sufi Tariqat: Competing for spiritual spaces in contemporary South(ern) Africa.", dalam http://www.uga.edu/islam/dawah_tariqat_sa.html, diakses tanggal 10 Desember 2006.

27 Pendidikan formalnya sampai tingkat doktoral dalam bidang teknik kimia di University of Istanbul, sedangkan pendidikan agama diperoleh dari kedua orang tuanya yang juga murshid tarekat Naqshabandîyah, Shaykh 'Abd Allâh Fâiz alDaghestânî. Setelah Shaykh Fâiz wafat pada 30 September 1973, ia diamanati untuk menggantikan kedudukannya sebagai murshid, dan sejak itu dikenal nama Tarekat Naqshabandi al-Haqqânî.
} 
negara baik di benua Eropa, Asia, maupun Afrika, yaitu: AS, Canada, Inggris, Spanyol, Swedia, Switzerland, Jerman, Belanda, Italia, Turkey, Mesir, Argentina, Brazil, Jepang, Malaysia, Singapura, Pakistan, Srilangka, Mauritus, dan Afrika Selatan.

Di Eropa Barat dan Amerika eksistensi tarekat diperkuat oleh pertumbuhan komuninas Muslim dalam jumlahnya tidak sedikit, baik melalui imigrasi maupun peralihan agama. Contohnya adalah ekspansi tarekat Nikmatullahi, yang pada tahun 1990 telah memiliki pusatpusat kegiatan di 9 kota besar di AS, dan bekerja dengan lembagalembaga akademis dalam mengorganisasi konferensi-konferensi tentang sufisme. ${ }^{28}$ Javad Nurbaksh (lahir 1926) yang memperoleh gelar doktor dari Universitas Sorbone dan menjadi guru besar psikiatri di Universitas Teheran yang mana sejak tahun 1983 menetap di London, adalah pemimpin tarekat Nikmatullahi yang berjasa dalam penyebaran tarekat ini ke luar wilayah Iran, khususnya AS, Eropa, dan Afrika. Hasil penelitian Ian Netton jelas menemukan bahwa Shaykh yang sekarang, yakni Javad Nurbakh sendiri, adalah telah mencapai peringkat ini. Dalam dirinya tercermin secara jelas Timur dan Barat, yang kuno dan yang modern, dan yang teologis dan teosofis. ${ }^{29}$ Dia juga telah menulis banyak buku tentang tasawuf, baik bahasa Persia maupun Inggris.

Meskipun demikian patut dicermati, berbeda dengan tarekat di kebanyakan negeri Muslim yang demikian massif, pengikut tarekat di negara-negara Barat dan Amerika Serikat jumlahnya tidak begitu signifikan bila dibandingkan dengan komunitas Muslim yang belum masuk tarekat, apalagi dengan komunitas agama lain. Hanya saja, karena di Barat kebebasan beragama dan ekspresi keberagamaan dijamin maka tarekat bisa eksis, bahkan seringkali komunitas yang dipandang langka semisal kaum tarekat dan gerakan kaum minoritas lain menjadi perhatian publik.

Hal penting lain, tarekat bisa berkembang di AS karena para pelakunya, sebagaimana semua penduduk negeri adidaya itu sudah terbebas dari masalah basic need (kebutuhan dasar) yang sering menjadi masalah bagi penduduk negara berkembang. Mereka tidak lagi harus memaksa diri berjuang untuk hidup, karena dengan jaminan biaya hidup minimal dari negara sudah menjadi point penting. Meskipun

\footnotetext{
${ }^{28}$ Voll, "Sufisme", 223.

29 Ian Richard Netton, Dunia Spiritual Kaum Sufi, terj. Machnun Husein (Jakarta: Rajawali Srigunting, 2001), 40-41.
} 
demikian para pemimpin tarekat sufi di Amerika bukanlah orang "biasa", umumnya mereka mempunyai keahlian dan disiplin keilmuan lain yang bisa dikembangkan. Faktor lain yang mendorong pertumbuhannya adalah karena pertemuan disiplin tarekat dengan perkembangan dalam ilmu psikologi di Barat yang cukup pesat, dan perpaduan keduanya ke dalam format psichology transendental menjadi tawaran menarik bagi masyarakarat negara maju.

Sementara itu di Indonesia, perkembangan tarekat pada era Orde Baru tetap memainkan peran penting. Memang benar, tidak semua puluhan tarekat yang ada di negeri ini dapat berkembang dengan pesat, tetapi yang pasti beberapa tarekat yang dapat berkembang baik seperti Tarekat Qâdirîyah wa Naqshabandîyah (TQN), Naqshabandîyah, Shâdhilîyah, Shațârîyah, Tỉjânîyah, dan Sammânîyah, sudah cukup sebagai bukti peran pentingya di era Indonesia kontemporer.

Pusat-pusat TQN yang tergolong besar adalah di Rejoso Jombang di bawah pimpinan K.H. Romly Tamim (w. 1957) dan penerusnya, di Mranggen terutama sewaktu dipimpin oleh K.H. Muslih (w. 1981), di Suryalaya oleh K.H. Shohibulwafa Tajul Arifin (1915-2011). Pusatpusat TQN ini kemudian berhasil mengembangkan jaringannya ke wilayah sekitar dan bahkan hingga ke luar provinsi, yang hingga kini masih dapat dilihat pengaruhnya.

K.H.A. Shohibulwafa Tajul Arifin yang lebih dikenal dengan sebutan Abah Anom, berhasil mendapatkan simpati yang luar biasa dari berbagai daerah, bahkan hingga ke mancanegara seperti Singapura, Malaysia, dan Brunei Darussalam. Besarnya jaringan yang berhasil dikembangkan oleh Abah Anom ini antara lain terlihat dari daftar wakil talqîn yang telah ditunjuk untuk membaiat atas namanya, hingga tahun 2010 tercatat sebanyak 89 orang wakil talqîn Pesantrennya ini menjadi unik dan kian terkenal setelah didirikannya Pondok Inabah sebagai pusat rehabilitasi bagi para korban narkotika dan obat-obat terlarang. ${ }^{30}$

TQN tersebut telah mengembangkan jaringannya di Jakarta. TQN Suryalaya untuk wilayah Jakarta terorganisasi secara baik yang berkantor di Plaza Ciputat dengan 104 pusat kegiatan se-Jabotabek. Popularitas TQN Suryalaya meningkat sesudah banyak pihak korban narkotika berhasil disembuhkan di pusat rehabilitasinya. Sementara itu

${ }^{30}$ Kharisuddin Aqib, Inabab: Jalan Kembali dari Narkoba Stres dan Kehampaan Jiwa (Surabaya: Bina Ilmu, 2005). 
TQN Rejoso juga berkembang di Jakarta lewat dua jalur: jalur langsung dari K.H. Mustain Romli yang kini dipimpin oleh K.H. Masyhuri Syahid MA, dan dari jalur K.H. Asrori yang dipimpin oleh Prof. Dr. Sofyan Tsauri yang mana acara khusîsîyah-nya setiap sabtu pagi menempati masjid Lembaga Ilmu Pengetahuan Indonesia (LIPI) Jakarta. ${ }^{31}$

Di Surabaya terdapat juga cabang TQN yang cukup berpengaruh yang berasal dari Cabang Rejoso Jombang yang dipimpin oleh K.H. Usman al-Ishaqi, murid K.H. Romli Tamim, berpangkal di Sawahpulo Surabaya. Jamaahnya cukup banyak yang ditandai antara lain ketika saat acara khusûsiyah dihadiri oleh sekitar 4.000 orang (lebih banyak dari TQN di Rejoso dan Cukir yang rata-rata 1.000 orang). ${ }^{32}$ Pada tahun 1984 ketika K.H. Usman wafat, kepemimpinan TQN dilanjutkan oleh puteranya, K.H. Ahmad Asrori (1952-2009), yang berpusat di Ponpes al-Fithrah Kedinding Lor, Surabaya. Popularitas TQN ini sampai juga ke wilayah Jawa Tengah, seperti Semarang, Pekalongan, dan Tegal, berkat siaran radio swasta di daerah ini yang menyiarkan secara langsung pengajian yang disampaikan oleh K.H. Asrori. Cabang ini sekarang telah berkembang ke berbagai wilayah di Jawa, Sumatera, bahkan hingga ke negeri jiran.

Sementara itu tarekat Naqshabandî Haqqânî dikenalkan di Indonesia oleh Shaykh Muḥammad Hishâm Kabbânî pada tahun 1997. Sejak saat itu tarekat ini terus berkembang antara lain ditandai dengan keberhasilannya membangun zâmîyah di kawasan Kampung Melayu. Pada kunjungan-kunjungan berikutnya banyak orang yang memperoleh baiat dari Shaykh Hishâm, dan di antaranya terdapat 5 orang yang ditunjuk sebagai wakil dari Shaykh untuk daerah-daerah di Indonesia: K.H. Mustofa Mas'ud (Jakarta), Ust. H. Wahfiuddin MBA (Jakarta), K.H. Ahmad Syahid (Bandung), K.H. Taufiqurrahman alSubky dan Habib Lutfi bin Yahya, keduanya dari Pekalongan. Tarekat di kota besar ini umumnya diikuti oleh golongan kelas menengah, mayoritas orang-orang muda terpelajar dan profesional..$^{33}$ Selain di

\footnotetext{
31 Ahmad Syafi'i Mufid, Tangklukan Abangan dan Tarekat (Jakarta: YOI, 2006), 243.

32 Mahmud Sujuthi, Politik. Tarekat Qadiriyah wa Naqshabandîyah Jombang (Yogyakarta: Galang Press, 2001), 89.

${ }^{33}$ Mufid, Tangklukan, 251.
} 
Jakarta, jaringan tarekat ini telah berkembang sampai ke Sukabumi, Bandung, Pekalongan, Surabaya, dan Batam. ${ }^{34}$

Tarekat Naqshabandîyah yang lain juga berkembang, khususnya Naqshabandîyah Shaykh Kadirun Yahya (w. 2002). Dia adalah menantu Shaykh Jalaluddin pemimpin Tarekat Naqshabandîyah Khâlidîyah di Sumatera Barat pada masa kemerdakaan dan pendiri PPTI (Partai Politik Tarekat Islam, kemudian berganti, Persatuan Pengamal Tarekat Islam). Ajaran Kadirun Yahya yang dipandang unik adalah pembahasannya mengenai metafisika sebagai ilmu pasti. ${ }^{35}$ Pengikut tarekat ini terdiri atas berbagai golongan sosial, dari kelas bawah, menengah, dan tinggi. Selain di Medan, pusat-pusat kegiatannya berkembang di sejumlah kota lain, antara lain: Pekanbaru, Bogor, Yogyakarta, Surabaya, Jember, Samarinda, dan Mataram.

Sementara itu tarekat Shâdhîlîyah, salah satu pusatnya terletak di kota Pekalongan, yang dipimpin oleh K.H. Habib Muhammad Lutfi. Beliau adalah murshid terkenal yang sekarang bertindak sebagai Raîs 'Âmm Idârah 'Âlîyah Jam'ŷyah Abl al-Taríqah al-Mu'tabarah al-Nahdîyah. Cabang ini berkembang di daerah Semarang, Kudus, Purwokerto, Jepara, dan Jakarta. Pusat Shâdhîlîyah lainnya adalah Pondok PETA (Pesulukan Thariqah Agung) di Tulungagung, yang dipimpin oleh K.H. Abdul Jalil Mustaqim, salah seorang guru spiritual mantan Presiden RI, Abdurrahman Wahid. Setelah beliau meninggal tahun 2005, dilanjutkan oleh putranya, Shaykh Sholahuddin, dan mendapat dukungan kuat dari Ust. Lukman Hakim-murid Kiai Jalil, penulis sejumlah buku, dan dikenal sebagai sufiolog. Lewat dialah Shâdhîlîyah Tulungagung dikenal luas melalui pengajian rutin di sejumlah tempat di Jakarta dan Surabaya.

\section{Kekuatan Tarekat dan Masuknya Kaum Kelas Menengah}

Salah satu sumber kekuatan tarekat hingga dapat bertahan sampai detik ini adalah soal otoritas mata rantai atau silsilah kemurshidannya. Daftar silsilah tarekat pada abad ke-20 umumnya mencantumkan sekitar 40 nama, dari yang terakhir nama murshid tarekat yang bersangkutan hingga terus sampai ke sahabat, lalu Rasulullâh saw, kemudian Malaikat Jibrîl, sampai akhirnya dari Allâh swt. Mata rantai ini sebagai jaminan bahwa ajaran tarekat yang dikembangkan benar-

34 Pusat Yayasan Haqqânî Indonesia berada di Jl. Tengku Umar No.41 Jakarta, Phone: 021-3153013 dan 021-3153014.

35 Martin van Bruinessen, Tarekat Naqshabandîyah di Indonesia (Bandung: Mizan, 1996), 148. 
benar autentik dan dapat dipertanggung-jawabkan. Dalam tradisi tarekat, tidak semua orang yang pernah dibai'at menjadi murid mempunyai kewenangan menjadi murshid. Menjadi murshid memerlukan prasyarat khusus yang tidak gampang. Dalam kitab Tanwîr al-Qulûb, yang menjadi rujukan pokok kalangan tarekat, disebutkan bahwa ada 24 kriteria yang harus dipenuhi seseorang untuk menjadi shaykh. ${ }^{36}$

Di samping, proses kesinambungan silsilah harus dilakukan melalui pemberian jjâzah (otorisasi, lisensi). ${ }^{37}$ Sang murshidlah yang menentukan siapa di antara para muridnya yang berhak memperoleh, dan dengan demikian, melanjutkan silsilah kemurshidannya. Jika seorang murid telah dianggap sampai pada tingkat tertentu dalam memahami haqaîqah, maka murshid akan mengangkatnya sebagai khalîfah dengan prosesi khusus. Sejauh ini tampaknya tidak ada rumusan pernyataan yang baku dalam sebuah ijâzah, kendati umumnya berisi penegasan bahwa shaykh tertentu (disebutkan nama lengkapnya) telah mengangkat murid tertentu (disebutkan pula nama lengkapnya) menjadi khalîfah, dan oleh karenanya murid tersebut memiliki kewenangan untuk menyampaikan ajaran tarekat. ${ }^{38}$

Kitab-kitab biografi para sufi banyak memuat hubungan gurumurid ini, misalnya yang ditulis oleh 'Abd al-Raḥmân al-Sulamî (w. 1030), pengarang kitab Ṭabaqât al-Sûfîyah. ${ }^{39}$ Kitab ini memuat 103 para sufi dari generasi pertama sampai kelima. Karya berbobot lain ditulis oleh Abû Nu'aym al-Aṣfahânî (w. 1038), Hilyat al-Awliyâ' wa Ṭabaqât al-Awliy $\hat{a}$. Ini merupakan kitab penting dan bernilai tentang biografi dan doktrin individual sufi, yang kini tercetak sepuluh volume. Ensiklopedi hagiografis ini, memasukkan bukan saja keempat alKhulafầ al-al-Râshidûn dan sederetan nama sahabat lain, namun juga keempat mazhab fiqh Sunnî. Secara keseluruhan karya ini memuat

\footnotetext{
36 Muhammad Amîn Kurdî, Tanwîr al-Qulûb (Semarang: Karya Toha Putera, t.th.), 524-527.

37 J. Spencer Trimingham, The Sufi Orders in Islam (New York: Oxford University Press, 1973), 304.

38 Aḥmad Khâtib Sambas, Fatḥ al-'Ârifin (Surabaya: Bungkul Indah, t.th.). Dalam kitab ini diuraikan tata cara bay'at zikir dan silsilah dalam Tarekat Qâdirîyah wa Naqshabandîyah secara lengkap.

39 'Abd al-Rahmân al-Sulamî, Tabaqât al-Ṣ̂fîyah, ed. Nur al-Dîn Sharîban (Kairo: Maktabat al-Khanaji, 1986).
} 
689 nama. $^{40}$ Dengan demikian, aspek silsilah merupakan faktor perennial yang menjadi kekuatan tarekat, karena terjaga kontinuitasnya sepanjang sekian abad lamanya.

Perlu ditambahkan bahwa dalam dunia tarekat, selain jenis ijâzah model tersebut, dikenal dua jenis ijâzah lain yang bobotnya lebih ringan, yaitu ijâzah yang diberikan kepada seorang murid yang sudah diizinkan untuk mengamalkan ritual atau zikir tertentu yang diajarkan oleh murshidnya, dan ijâzah yang diberikan kepada seorang murid yang dianggap telah menyelesaikan tahap tertentu dari ajaran tarekat yang diberikan gurunya. Berbeda dengan model ijâa $a h$ terdahulu, dua jenis jjâzah yang terakhir ini tidak memberikan kewenangan kepada yang menerimanya untuk menahbiskan orang lain menjadi anggota tarekat, melainkan hanya untuk yang bersangkutan saja.

Bagi tarekat yang tidak dapat menunjukkan silsilahnya, atau diduga keras membuat daftar fiktif, atau ada murshid tarekat yang mengaku menerima pengajaran langsung dari Nabi Muhammad saw, biasanya sulit berkembang atau menjadi terpinggirkan, karena dinilai tidak memiliki autentisitas otoritas yang bersambung secara langsung sampai kepada Rasulullâh. Demikianlah betapa pentingnya konsep silsilah ini dalam tradisi tarekat sebagai sumber otoritas. Jika kita hubungkan dengan kondisi sekarang, konsep "otoritas" dalam pengertian luas tetaplah mendapat pengakuan hingga masa kontemporer sekarang ini, baik oleh komunitas Muslim sendiri maupun oleh masyarakat Barat. Misalnya yang tercermin dalam tradisi keharusan adanya rekomendasi dari seorang dosen senior/profesor bagi mahasiswa yang akan melanjutkan studi ke jenjang pascasarjana.

Faktor lain yang dapat dipandang sebagai kekuatan tarekat adalah adanya reformasi yang dilakukan olek kalangan internal. Rektor Universitas al-Azhar 1973-1978, 'Abd al-Halîm Mạ̣mûd, seorang ulama Shâdhiliyah misalnya, menekankan pentingnya reformasi. Menurutnya, tarekat-tarekat Mesir mengalami kemunduran, dan ia menganjurkan untuk kembali kepada sumber klasik agar dapat menemukan kembali bentuk sufisme yang autentik yang menekankan pada tanggungjawab sosial. Ia yakin bahwa hal ini dapat dicapai melalui reformasi di jalan tarekat Shâdhilîyah, sebagaimana dituangkan dalam karyanya, al-Madrasah al-Shâdhilîyah al-Hadîthah. ${ }^{41}$

\footnotetext{
40 Abû Nu'aym al-Așfahânî, Hilyat al-Awliyâ' wa Tabaqât al-Asfiyâ' (Beirut: Dâr alKutub al-Ilmîyah, t.th.).

${ }^{41}$ Sirriyeh, Sufi, 224.
} 
Perkembangan aliran Shadhilîyah di Mesir cukup bagus, seperti ditunjukkan sub Ḥamîdîyah yang didirikan oleh seorang pegawai sipil, Shaykh Salâma Hasan al-Râdî (1867-1939). Organisasi yang seruan awalnya ditujukan pada orang-orang miskin di Kairo dan Delta Sungai Nil ini telah berhasil mengumpulkan sejumlah anggota kelas menengah yang telah terpengaruh dan bergerak dalam tarekat dengan arahan yang lebih reformis. Mereka lebih menekankan pada kemampuan-kemampuan intelektual shaykh pendirinya dibanding bakat-bakat ajaibnya. Pada akhirnya mereka dapat membangun sarana dengan baik, masjid yang megah, pusat pendidikan, perpustakaan, dan fasilitas-fasilitas lainnya di distrik Zamalek, Kairo. ${ }^{42}$

Selain karena faktor-faktor di atas dapat membuat daya tahan tarekat, tradisi kepeloporan dalam tarekat juga dapat dipandang sebagai kekuatan adaptif yang luar biasa. Seperti ditunjukkan dalam tradisi kemurshidan tarekat Qâdirîyah, bilamana seseorang murid sudah mencapai maqâm tertentu dan memperoleh ijâzah sebagai murshid, maka dia memiliki kebebasan, tidak harus terikat dengan metode yang diberikan murshid sebelumnya dan bisa membuat metode riyâdât tersendiri. ${ }^{43}$ Karena itu tidaklah mengherankan bila Qâdirîyah cepat berkembang dan tersebar, sehingga menjadi tarekat terbesar di dunia yang memiliki cabang-cabang dan sub-cabang yang kemudian berdiri secara independen. Dalam penelitiannya, Trimingham menyebut ada 29 grup yang bernaung di bawah bendera Qâdirîyah yang tersebar berbagai negeri Muslim. ${ }^{44}$ Ini menunjukkan bahwa dinamika kebebasan bagi murshid dalam tarekat cukup besar, sesuatu yang amat mungkin tidak pernah dibayangkan oleh mereka yang selama ini getol mengritik tarekat sebagai institusi yang statis.

Di Eropa Timur terutama di Albania, Kosovo, dan Bulgaria, tarekat Bektasyiah dapat bertahan karena karakter eklektisismenya, seperti melakukan perayaan keagamaan bersama dengan pihak nonMuslim. Dengan eklektisismenya, tarekat ini mempunyai peran besar dalam menumbuhkan toleransi, akomodasi, dan saling pengertian dengan masyarakat Kristen Ortodoks setempat. Dalam masa kejayaan rezim-rezim komunis yang berusaha memberantas pengaruh agama, tarekat ini sebagian tetap bertahan. Pusat tasawuf dan tarekat seperti

\footnotetext{
42 Ibid., 222.

43 Amîr al-Najjâr, Al-Ṭuruq al-Sûfìyah fî al-Miṣr (Kairo: Maktabah Anjalû al-Mișrîyah, t.th.), 115.

44 Trimingham, The Sufi Orders, 271-273.
} 
di Sarajevo (Bosnia), Ruscuk, Razgrad, dan Sumen (semuanya di Bulgaria) tetap aktif dalam kegiatan-kegiatan sufistik untuk kemudian mengalami kebangkitan setelah kebangkrutan komunisme. ${ }^{45}$

Tentang ciri eklektisisme tarekat ini perlu diberi catatan khusus, yaitu bahwa ia bukanlah prasyarat utama dapat bertahannya tarekat, akan tetapi lebih pada upaya menyiasati keadaan agar sufisme dan tarekat dapat diterima pihak lain ketika ia dalam posisi minoritas. Pada sisi lain kecenderungan ke arah eklektisisme dapat menimbulkan kekhawatiran terjadinya erosi besar-besaran dalam tradisi sufisme, sehingga ia akan banyak kehilangan nilai dasarnya. Karena itu para ulama telah melakukan proteksi lewat kritik sebagai mekanisme kontrol agar tarekat tetap berkembang tanpa kehilangan pijakannya yang asli. Dalam konteks inilah seharusnya kita membaca fenomena pembedaan antara tarekat mu'tabarah dan ghayr mu'tabarah yang dicetuskan pada pertengahan abad ke-20 di tanah air. Sudah menjadi maklum bahwa waktu itu, bahkan sejak lama sebelumnya, perkembangan aliran kebatinan cukup signifikan khususnya di Jawa, sehingga sering masyarakat awam tidak bisa membedakan mana ajaran tarekat dan mana yang kejawen.

Di AS dan negara Barat lainnya, tasawuf dan tarekat dapat hidup dan berkembang karena watak cinta dan perdamaian seringkali disuarakan oleh para tokohnya, terutama dari kalangan tarekat Chistîyah dan Nikmatullahi. Tasawuf adalah "agama" masa depan, persisnya agama satu-satunya yang dapat menyatukan umat dalam perdamaian. Selain Inayat Khan, Vilayet Inayat Khan, Javad Nurbakhs, Bawa Muhaiyaddeen adalah tokoh yang patut disebut. Dia adalah pir sufi asal Sri Lanka yang populer sejak 1970-an. Dia sangat menekankan aspek "cinta", bahkan tasawuf yang dikembangkannya merupakan semacam sintesis antara tasawuf dan Hinduisme, walaupun istilah yang digunakan hampir seluruhnya diambil dari terminologi tasawuf.

Tasawuf dan tarekat secara historis sangat dekat kapada tradisi perkotaan (urban). Pusat-pusat tarekat sejak awal kemunculannya berkembang di sejumlah kota, seperti Baghdad, Bashrah, dan Damaskus. Salah satu contohnya adalah tarekat Qâdirîyah yang dipandang sebagai paling tua. Meskipun 'Abd al-Qâdir lahir di Jîlan, tapi ia belajar dan berkembang di kota Baghdad. Di sinilah dia berhasil menapaki jalan spiritual di bawah bimbingan gurunya, al-

45 Azra, “Tasawuf”, 391. 
Dabbâs (w.1191). Sejak tahun 1127 dia mulai berceramah di depan umum dan pengikutnya tumbuh secara mantap. Pada tahun 1134 dia dilantik sebagai kepala sebuah madrasah, tempat orang mulai tertarik kepada kekuatan ceramahnya, sehingga sebuah ribât dibangunkan untuknya di dekat gerbang kota ${ }^{46}$ Dari fakta ini dapat dipahami, perkembangan ribât yang dipimpinnya lambat laun memperoleh pengikut yang kian banyak berkat ketokohannya serta posisi pusat penggemblengan kaum sufi itu yang berada di kawasan kota. Pada saat itu Baghdad belum jatuh ke tangan Mongol, dan meskipun kekuatan politik Baghdad sudah mulai menyusut, namun pamornya sebagai pusat akademik dan kebudayaan Islam masih tetap kokoh. Para penuntut ilmu dari berbagai penjuru selalu ramai mengunjungi Baghdad untuk belajar kepada para ulamanya, sebelum kemudian mereka menjadi ulama yang menggantikannya. Kiranya tidak berlebihan jika tarekat Qâdirîyah disebut sebagai "tarekat kota". Penilian serupa diberikan oleh Gibb demikian: The most typical urban orders is that of Qadiriya, named after Abd al-Qadir al-jilani or Gilani. ${ }^{47}$

Fakta di atas secara jelas membuktikan bahwa tarekat awalnya tumbuh di kawasan perkotaan, yang mencerminkan budaya kosmopolit. Meskipun sekarang ini di Indonesia keberadaan tarekat lebih banyak diikuti oleh penduduk pedesaan, pada awalnya pusat tarekat tetaplah di kota. Secara lebih khusus, TQN sebagai tarekat yang paling luas pengaruhnya di Indonesia, awalnya berpusat di kota suci Makkah. Tarekat ini dipopulerkan oleh Shaykh Aḥmad Khatîb Sambas (1805-1878) di Makkah sebagai pusat pendidikan Islam dan pencetak ulama'. Ia adalah murid Shaykh Shams al-Dîn, murshid tarekat Qâdirîyah, yang kemudian berhasil menapaki jalan tarekat ini hingga layak memperoleh sebutan sebagai murshid kâmil mukammil. Dari pusat kota Makkah inilah kemudian TQN tersebar ke berbagai wilayah Indonesia melalui tiga khalîfahnya yaitu: Shaykh 'Abd alKarîm Banten, Shaykh Tolḥah Cirebon, dan Shaykh Wahab Hasbullâh Madura. ${ }^{48}$

Selain kota Makkah dikenal sebagai pusat dinamika awal pertumbuhan Tarekat Qâdirîyah wa Naqshabandîyah, sudah sejak lama Tarekat Naqshabandîyah memiliki jaringan kuat di kota ini.

\footnotetext{
${ }^{46}$ Fazlur Rahman, Islam (Chicago: University of Chicago Press, 1979), 158.

${ }^{47}$ H.A.R. Gibb, Mohammedanism: A Historical Survey (London: McMillan, 1969), 105.

48 Zulkifli, Sufism in Java: The Role of the Pesantren in the Manintenance of Sufism in Java (Jakarta: INIS, 2002), 15-17.
} 
Tokoh yang sering disebut-sebut adalah 'Abd Allâh al-Arjinjânî (dari Erzincan Turki Tengah) yang telah membangun sebuah zâwîyah di Jabal Abû Qubais, dan mempunyai beberapa murid dari Indonesia. Sulaimân al-Qirîmî dan Sulaimân Zuhdî juga dipandang sebagai pemimpin yang mewarisi dinamika zâmîyah di kota suci, khususnya yang terakhir, dikenal sebagai Shaykh Jabal Abû Qubays atau Shaykh Jabal. ${ }^{49}$ Dengan data ini dapat dipastikan bahwa Makkah benar-benar pernah menjadi pusat pertumbuhan tarekat, meskipun tarekat-tarekat tersebut umumnya bukan lahir di rahim tanah suci ini.

Madinah, tidak diragukan lagi, juga merupakan pusat tarekat khususnya Sammânîyah yang didirikan oleh Muhammad b. 'Abd alKarîm al-Madanî al-Sammân (1718-1775). Dia banyak menghabiskan hidupnya di Madinah, tinggal di rumah bersejarah milik Abû Bakr alȘiddîq, dan bertindak sebagai penunggu makam Rasulullâh saw. Di tanah air, Tarekat Sammânîyah kini berkembang di Sulawesi Selatan, Kalimantan Selatan, dan Palembang. Sultan Palembang tercatat memiliki andil dalam pertumbuhan Tarekat Sammânîyah. Tercatat bahwa Sultan Maḥmûd Baha' al-Dîn pada tahun 1776 memberi uang wakaf sebesar 500 real untuk kepentingan zâwiyah tarekat ini di Jeddah, yang selanjutnya juga berfungsi untuk menampung jamaah haji dari Palembang dalam perjalanannya menuju Makkah. ${ }^{50}$

Dengan demikian hubungan Haramain dan kawasan Nusantara sejak abad ke-17 telah mendorong berkembangnya tradisi intelektual di satu sisi, dan maraknya hubungan guru-murid dalam silsilah tarekat pada sisi lain. Zâmîyah-zâmîyah di kota Makkah, Madinah, dan Jeddah cukup menjadi bukti bahwa tarekat diterima oleh para jemaah haji, yang secara sosial ekonomi, dapat dipandang sebagai kelompok "kelas menengah". Saat itu tidak mudah bagi Muslim Nusantara di era kolonial untuk dapat menunaikan ibadah haji, selain biaya yang tidak sedikit juga karena adanya berbagai peraturan pemerintah Belanda yang ketat. $^{51}$ Kalangan kelas menengah ini semakin banyak yang menunaikan ibadah haji, terutama setelah dibukanya terusan Suez tahun 1869, dan setelah dioperasionalkannya kapal uap. Era ini dan tahun-tahun berikutnya merupakan era penting pematangan gerakan

\footnotetext{
49 Bruinessen, Tarekat Naqshabandîyah, 67.

${ }^{50}$ Mulyati (ed.), Tarekat Muktabarah, 193.

${ }^{51}$ Karel A. Steenbrink, Beberapa Aspek tentang Islam di Indonesia Abad Ke-19 Jakarta: Bulan Bintang, 1984), 235.
} 
tarekat di tanah suci, sebelum kemudian berhenti secara mendadak akibat dikuasainya Makkah oleh kaum Wahabi tahun 1924.

Insitusi tarekat makin kuat karena ditopang oleh masuknya kalangan terdidik dan kelas menengah. Dari daftar wakil talqin TQN Suryalaya sebagaimana pernah dimuat dalam situsnya, dari 89 nama wakil talgîn untuk berbagai wilayah di Indonesia terdapat sejumlah nama kaum terdidik yang bergelar Doktor dan bahkan juga Profesor, seperti: Juhaya S. Praja, HM. Zurkani Yahya, Ahmad Tafsir, dan Abd. Jabar Malik. Beberapa kalangan intelektual ini memiliki reputasi yang baik di kampusnya, karena itu masuknya mereka ke dunia tarekat dapat menginspirasi kalangan akademis lain.

Sebagaimana dijelaskan sebelunya, tarekat-tarekat berkembang luas di berbagai kota besar, dan pengikutnya juga beragam, termasuk dari kalangan kelas menengah. Patut dipertanyakan, apa yang menjadi motivasi kalangan the have ini masuk tarekat? Apakah gejala tersebut hanya sebagai eskapisme dalam dunia modern, atau disebabkan oleh kegagalan organized religion? ${ }^{52}$ Secara umum kecenderungan faktorfaktor itu memang ada. Akan tetapi fakta lebih detail menunjukkan bahwa kalangan kelas menengah masuk tarekat karena banyak faktor. Ada faktor psikologis untuk memperdalam pengalaman keagamaan, bukan sebagai pelarian, namun benar-benar tumbuh dari keinginan instrinsiknya. Ada faktor sosial, karena mereka mencari in group yang bisa menegaskan identitas keagamaannya sehingga mampu menjadi daya dukung yang kuat. ${ }^{53}$ Faktor ekonomi-politik juga ada, yang mana banyak kalangan pebisnis dan usahawan merasa mendapat perlindungan di bawah otoritas sang kiai, sementara mereka tidak mendapat perlakuan yang adil dari kebijakan pemerintah. Kiai sebagai generic name, dan juga murshid tarekat, sering mampu memainkan peran demikian seperti dicontohkan oleh sejumlah kiai yang dikenal memiliki basis massa luas.

Penting dicatat, faktor instrumental berupa publikasi dan media menjadi daya dongkrak tersendiri untuk makin dikenalnya tarekat di kalangan masyarakat kota. TQN pimpinan K.H. Asrori Surabaya ternyata cukup berkembang di Jawa Tengah. Salah satu faktor pendukungnya adalah karena adanya fasilitas media elektronik yang menyiarkan pengajian-pengajian beliau. Media yang dimaksud adalah

52 Allen E. Bergin, "Spiritualitas Abad Modern”, Ulumul Qur'an, Vol. 6, No. 4 (1994).

${ }^{53}$ Ahmad Najib Burhani, Sufisme Kota (Jakarta: Serambi, 2001), 161. 
radio-radio swasta di sejumlah kota, seperti: Ungaran (Radio Rasika FM), Semarang ("W" FM), Kendal (Citra FM), Pekalongan (Amarta FM), dan Tegal (Suara Tegal AM), yang secara rurin menyiarkan siraman rohani oleh K.H. Asrori. Tidak hanya itu, setiap pertengahan bulan Qamarîyah, pembacaan Manâqib Shaykh 'Abd al-Qâdir al-Jilânî juga disiarkan. ${ }^{54}$ Fakta ini membuat beliau makin diakui ketokohannya, sekaligus membuka lebar-lebar bagi masuknya muridmurid baru tarekat.

Sedangkan Tarekat Shâdhilîyah pondok PETA Tulungagungyang kini sudah berkembang sampai ke Jakarta, Bandung, dan Surabaya-, menjadi dikenal luas antara lain berkat suatu media yang dipimpin oleh orang dekat (alm) K.H. Abdul Jalil Mustaqim, ust. Luqman Hakim. Cabaya Sufi, majalah bulanan yang terbit sejak beberapa tahun lalu itu diminati banyak kalangan terutama karena kolom-kolomnya: psikologi sufi, konsultasi sufi, dan cuplikan ajaran tasawuf dari karya-karya Ibn 'Ațâ' Allâh, 'Abd al-Qâdir al-Jîlânî, Abû Naṣr al-Sarrâj al-Tûfî, dan yang lainnya. Kolom surat pembaca dan tanya jawab mudah menjadi bahan diskusi hangat lantaran prosesnya lewat email sehingga pengasuh dapat segera memuatnya pada edisi berikutnya, atau jawaban hanya di-replay khusus kepada penanya apabila yang bersangkutan menyatakan "tidak untuk dipublikasikan". Sekadar contoh pertanyaan yang muncul, misalnya seputar "semangat ibadah kok menurun", "aku resah aku gelisah", "affair teman sekantor", "ingin mengenal Allah", "apakah mesti bertarekat", "model duduk orang zikir", dan "sudah bertarekat tapi masih berkubang maksiat". ${ }^{55}$ Dalam hal pengasuh memberikan jawaban, semuanya dengan perspektif sufisme, dan bahkan dengan patokan-patokan yang standar sesuai dalam tradisi tarekat.

Selain itu, satu faktor lagi yang penting adalah peran lembaga penyokong. TQN al-Utsmaniyah semakin terasa kencang sejak tahun 1990an pada saat dibentuk al-Khidmah, sebuah yayasan dan perkumpulan untuk jamaah tarekat. Al-Khidmah inilah yang merupakan penyangga-penyokong tumbuhkembangnya jamaah tarekat, mulai ke daerah pedesaan hingga ke pelbagai kota besar di tanah air. Al-Khidmah juga yang mendesain jadwal acara-acara zikir

54 Tim Redaksi, "Dinamika TQN Al-Utsmaniyah", Aula, No. 1, Tahun XXVII (Januari 2006), 68-71.

55 M. Lukman Hakim, "Konsultasi Sufi", Cahaya Sufi (November 2006), 29-40 dan 79-97. 
dan Mawlid al-Rasûl di sejumlah kawasan, bahkan hingga ke Singapura dan Malaysia. Al-Khidmah cukup leluasa memainkan peran-peran strategis, termasuk membentuk sub-kelompok di dalamnya, yang disebut al-Khidmah kampus.

Dengan berbagai perubahan kemajuan institusi tarekat tersebut menggambarkan adanya revitalisasi dari dalam, dan menunjukkan kepada publik bahwa tarekat tetap diminati. Hanya saja, di antara sekian banyak kalangan kelas menengah kota yang ada di negeri ini, hanyalah sebagian kecil saja yang secara sadar menjatuhkan pilihan untuk bergabung dengan tarekat. Bukankah golongan kelas menengah di Indonesia pertumbuhannya tidak alami? Bahkan tidak sedikit yang menuding buruknya perilaku ekonomi-politik mereka ini, sehingga eksistensinya menjadi eksklusif dan tidak bisa memperkuat jaringan masyarakat sipil. ${ }^{56}$ Untuk kalangan demikian, biasanya jika mendekat ke arus spiritualitas, mereka lebih memilih pada bentuk-bentuk yang populer. Lain halnya dengan kalangan kelas menengah yang tumbuh secara wajar dan memiliki kepekaan religius, mereka cenderung lebih memilih gerakan spiritual yang serius.

\section{Penutup}

Fenomena berkembangannya tarekat di masyarakat perkotaan merupakan hal menarik, karena sebelumnya tarekat seringkali diidentikkan dengan aktivitas masyarakat pedesaan tradisional, bahkan dianggap sebagai simbol ketertinggalan. Dengan masuknya kelompok kelas menengah ke dalam jaringan tarekat ternyata membawa angin segar perubahan dan menyuplai dinamika internal yang tumbuh subur. Secara umum dapat ditegaskan, ada tiga argumentasi mengapa tarekat berkembang di kawasan perkotaan: pertama, karena tarekat menjadi sarana pencarian makna hidup; kedua, tarekat sebagai sarana terapi psikologis; dan ketiga sebagai sarana memperteguh tradisi keagamaan.

Pada akhirnya, dinamika tarekat di kawasan perkotaan tidak dapat dipandang remeh mengingat ia telah memiliki modal sosial yang memadai untuk bisa berkembang lebih jauh, meskipun banyak hal yang menjadi kendala. Sementara itu kursus-kursus dan pengajian tasawuf, pelatihan ESQ, hingga pelatihan salat khushô adalah beberapa contoh fenomena sufisme kontemporer Indonesia yang berhasil menyuguhkan konsep, strategi, dan pengalaman kerohanian yang diminati kalangan luas. Meskipun perkembangan sufisme tak

56 Loekman Sutrisno, "Pergeseran dalam Golongan Menengah di Indonesia", Prisma, No. 2 (Pebruari 1984), 23-29. 
terstruktur cukup signifikan, hal itu tidaklah membuat tarekat mandeg. Justru kelebihan tarekat terletak pada pengembangan personal religiousity yang lebih evolutif dan mendalam, dari pada sekadar pengalaman instan yang sering dialami mereka yang pernah ikut dalam program sufisme non-tarekat. Walhasil, tarekat, tentu saja dengan "wajah baru"-nya tetaplah menjadi salah satu alternatif signifikan bagi penyaluran emosi keagamaan masyarakat Muslim perkotaan.

\section{Daftar Rujukan}

Anwar, Khairul. "Al-Ma‘âhid al-Turâthîyah wa al-Shuyûkh wa alTuruq al-Ṣûfiyah”, Studia Islamika, Vol. 5, No. 1, 1998.

Aqib, Kharisuddin. Inabah: Jalan Kembali dari Narkoba Stres dan Kehampaan Jiwa. Surabaya: Bina Ilmu, 2005.

Arbery, A.J. Sufism: An Account of the Mystic of Islam. London: George Allen and Unwin, 1950.

Aṣfahânî (al), Abû Nu'aym. Hilyat al-Awliyâ' wa Tabaqât al-Asfiyâ'. Beirut: Dâr al-Kutub al-Ilmîyah, t.th.

Azra, Azyumardi. "Tasawuf dan Tarekat", dalam Taufik Abdullah (ed.). Ensiklopedi Tematis Dunia Islam: Dinamika Masa Kini, Vol. 6. Jakarta: Ichtiar Baru van Hoeve, 2002.

Bergin, Allen E. "Spiritualitas Abad Modern”, Ulumul Qur'an, Vol. 6, No. 4, 1994.

Bruinessen, Martin van. "The Origin and Development of Sufi Order (Tarekat) in Southeast Asia", Studia Islamika, Vol. 1, No. 1, AprilJuni 1994.

----. Kitab Kuning Pesantren dan Tarekat. Bandung: Mizan, 1999.

Tarekat Naqshabandîyah di Indonesia. Bandung: Mizan, 1996.

Burhani, Ahmad Najib. Sufisme Kota. Jakarta: Serambi, 2001.

Christomy, Tommy. "Shațâriyah Tradition in West Java: the Case of Pamijahan", Studia Islamika, Vol. 8, No. 2, 2001.

Geertz, Clifford. Abangan Santri Priyayi dalam Masyarakat Jawa, terj. Aswab Mahasin. Jakarta: Pustaka Jaya, 1989.

Gibb, H.A.R. Mohammedanism: A Historical Survey. London: McMillan, 1969.

Hakim, M. Lukman. "Konsultasi Sufi”, Cahaya Sufi, November 2006. Hamzeh, A. Nizar dan Dekmejian, R. Hrair. "A Sufi Response to Political Islamism: Al-Ahbasy of Lebanon", International Journal of Middle East Studies, 28, 1996. 
Haron, Muhammed. "The Dawah Movements and Sufi Tariqat: Competing for spiritual spaces in contemporary South(ern) Africa.", dalam http://www.uga.edu/islam/dawah_tariqat_sa. html, 10 Desember 2006.

Jamil, Muksin. Tarekat dan Dinamika Sosial Politik. Yogyakarta: Pustaka Pelajar, 2005.

Johansen, J.E.A. "Sufisme dan Politik", dalam John L. Esposito (ed.), Ensiklopedi-Oxford Dunia Islam Modern, Vol. 5, terj. Eva, et al. Bandung: Mizan, 2002.

Kahmad, Dadang. Tarekat dalam Islam: Spiritualitas Masyarakat Modern. Bandung: Pustaka Setia, 2002.

Keddie, Nikki (ed.). Scholars Saints and Sufis. Barkeley, Los Angeles, dan London: University of California Press, 1972.

Kurdî, Muhammad Amîn. Tanwîr al-Qulûb. Semarang: Karya Toha Putera, t.th.

Lammens, H. Islam: Beliefs and Institutions. New Delhi: Oriental Bokks Reprint Corporation, 1979.

Mu'tashim, Rajasa dan Mulkhan, A. Munir. Bisnis Kaum Sufi. Yogyakarta: Pustaka Pelajar, 1998.

Mufid, Ahmad Syafi'i. Tangklukan Abangan dan Tarekat. Jakarta: YOI, 2006.

Muhaimin. "Pesantren and Tarekat in Modern Era: An Account on the Transmission of Traditional Islam in Java", Studia Islamika, Vol. 4, No. 1, 1997.

Najjâr (al), Amîr. Al-Turuq al-Șúfíyah fì al-Miṣr. Kairo: Maktabah Anjalû al-Mișrîyah, t.th.

Nasr, Sayyed Hossein. Ensiklopedi Tematis Spiritualitas Islam, terj. M. Solihin, et al. Bandung: Mizan, 2003.

Netton, Ian Richard. Dunia Spiritual Kaum Sufi, terj. Machnun Husein. Jakarta: Rajawali Srigunting, 2001.

O'Brien, Donal B. Cruise. Saints and Politicians: Essays in the Organization of a Senegalese Peasant Society. Cambridge: Cambridge University Press, 1975.

----- The Mourides of Senegal. Oxford: Oxford University Press, 1971.

Rahman, Fazlur. Islam. Chicago: University of Chicago Press, 1979.

Redaksi, Tim. "Dinamika TQN Al-Utsmaniyah", Aula, No. 1, Tahun XXVII, Januari 2006. 
Sambas, Aḥmad Khâtib. Fatḥ al-'Ârifin. Surabaya: Bungkul Indah, t.th. Schimmel, Annimarie. Mystical Dimensions of Islam. Chapel Hill: The University of Nort Carolina Press, 1975.

Sirriyeh, Elizabeth. Sufi dan Anti Sufi, terj. Ade Alimah. Yogyakarta: Pustaka Sufi, 2003.

Steenbrink, Karel A. Beberapa Aspek tentang Islam di Indonesia Abad Ke19. Jakarta: Bulan Bintang, 1984.

Sujuthi, Mahmud. Politik Tarekat Qadiriyah wa Naqshabandîyah Jombang. Yogyakarta: Galang Press, 2001.

Sulamî (al), 'Abd al-Rahmân. Tabaqât al-Sûfîyah, ed. Nûr al-Dîn Sharîban. Kairo: Maktabah al-Khanaji, 1986.

Sutrisno, Loekman. "Pergeseran dalam Golongan Menengah di Indonesia”, Prisma, No. 2, Pebruari 1984.

Syam, Nur. Pembangkangan Kaum Tarekat. Surabaya: Lepkiss, 2004.

Tohir, Ajid. Gerakan Politik Kaum Tarekat: Telaah Historis Gerakan Antikolonialisme Tarekat Qadiriyah wa Naqshabandîyah di Pulau Jawa. Bandung: Pustaka Hidayah, 2002.

Trimingham, J. Spencer. The Sufi Orders in Islam. New York: Oxford University Press, 1973.

Turmudi, Endang. Perselingkuhan Kiai dan Kekuasaan. Yogyakarta: LKiS, 2004.

Voll, John O. "Mahdis, Walis and New Men in the Sudan", dalam Nikki Keddie (ed.). Scholars Saints and Sufis. Barkeley, Los Angeles, dan London: University of California Press, 1972.

-----. "Sufism: Tarekat-tarekat Sufi", dalam John L. Esposito (ed.), Ensiklopedi Oxford Dunia Islam Modern, Vol. 5, terj. Eva, et al. Bandung: Mizan, 2002.

Ziadeh, Nicola A. Sanusiyah: A Study of a Revivalist Movement in Islam. Leiden: E.J. Brill, 1983.

Zulkifli. Sufism in Java: The Role of the Pesantren in the Manintenance of Sufism in Java. Jakarta: INIS, 2002. 